\title{
Pengaruh Merokok Terhadap Kadar Asam Urat pada Pria Dewasa yang Mengonsumsi Tuak di Kelurahan Sigulang-gulang Kecamatan Siantar Utara
}

\author{
Novri Angelina Tambunan, Malayana Rahmita Nasution \\ Departemen Patologi Klinik, Fakultas Kedokteran, Universitas Sumatera Utara, Medan
}

\begin{abstract}
ABSTRAK
Latar Belakang: Asam Urat (AU) adalah senyawa nitrogenik $\left(\mathrm{C}_{5} \mathrm{H}_{4} \mathrm{~N}_{4} \mathrm{O}_{3} / 2,6,8\right.$-trihidroksipurin) yang merupakan produk akhir katabolisme purin nukleosida adenosin dan guanosin. Kadar asam urat dipengaruhi oleh usia, asupan senyawa purin, konsumsi alkohol, indeks massa tubuh (IMT), aktivitas fisik, hipertensi, penyakit jantung, obat-obatan tertentu dan gangguan fungsi ginjal. Tujuan: Tujuan penelitian ini adalah untuk mengetahui pengaruh merokok terhadap kadar asam urat pada pria dewasa yang mengonsumsi tuak. Metode: Penelitian ini merupakan penelitian dengan metode analitik dengan desain penelitian cross sectional. Pengambilan data dilakukan hanya satu kali untuk mengumpulkan data primer dengan alat ukur berupa kuesioner untuk mengetahui kebiasaan konsumsi tuak dan merokok dan Autocheck untuk mengukur kadar asam urat. Populasi dalam penelitian ini adalah seluruh pria dewasa di Kelurahan Sigulang-gulang, Kecamatan Siantar Utara. Penentuan sampel dilakukan dengan cara consecutive sampling. Data yang telah dikumpul akan diolah dan dianalisis dengan menggunakan software SPSS. Hasil: Hasil penelitian menunjukkan terdapat perbedaan kadar asam urat pada pria dewasa yang merokok dan mengonsumsi tuak dengan pria dewasa yang tidak merokok dan mengonsumsi tuak dengan nilai $p$ bermakna $(6,01 \pm 1,09$ vs $7,31 \pm 1,20$; $<<0,001)$. Kesimpulan: Penelitian ini menyimpulkan terdapat pengaruh merokok terhadap kadar asam urat pada pria dewasa yang mengonsumsi tuak.
\end{abstract}

Kata Kunci: asam urat, merokok, tuak

\begin{abstract}
Background: Uric acid (UA) is a nitrogen compound $\left(\mathrm{C}_{5} \mathrm{H}_{4} \mathrm{~N}_{4} \mathrm{O}_{3} / 2,6\right.$, 8-trihydroxypurine) which is the final product of purine catabolism nucleoside adenosine and guanosine. Uric acid levels are influenced by age, purine intake, alcohol consumption, body mass index (BMI), physical activity, hypertension, heart disease, certain medications, and impaired renal function. Objectives: This study aims to determine the influence of smoking on uric acid levels in adult men who drink tuak. Methods: This study used an analytic method using a cross-sectional design. Data retrieval is performed only once for collecting primary data with measuring instruments in the form of a questionnaire and Autocheck to measure uric acid levels. The population in this study is all adult men in Sigulanggulang, North Siantar. Consecutive sampling was used to determine the number of samples. The data obtained will then be processed and analyzed using SPSS software. Results: The results show that there are differences in uric acid levels in adult men who smoke and drink tuak compare to adult men

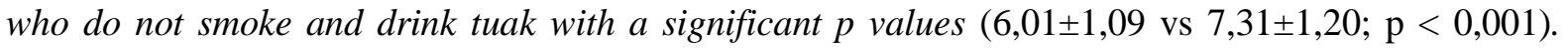
Conclusion: This study concluded that there is an influence of smoking on uric acid levels in adult men who drink tuak.
\end{abstract}

Keywords: smoking, tuak, uric acid

Received [1 Jan 2020] | Revised [23 Oct 2020] | Accepted [16 Nov 2020] 


\section{PENDAHULUAN}

Asam urat adalah senyawa nitrogenik $\left(\mathrm{C}_{5} \mathrm{H}_{4} \mathrm{~N}_{4} \mathrm{O}_{3} / 2,6,8\right.$-trihidroksipurin) yang merupakan produk akhir katabolisme purin nukleosida adenosin dan guanosin. Asam urat (AU) terutama dihasilkan oleh hati, $400 \mathrm{mg} /$ hari dan $300 \mathrm{mg}$ dari diet. $^{[1]}$ Hiperurisemia adalah peningkatan kadar AU darah di atas normal. Hiperurisemia dapat terjadi karena peningkatan metabolisme AU (overproduction), penurunan pengeluaran AU urin (underexcretion), atau gabungan keduanya. Untuk laki-laki, ambang normalnya adalah $7,0 \mathrm{mg} / \mathrm{dL}$. Adapun pada perempuan normalnya adalah $6 \mathrm{mg} / \mathrm{dL}$ darah. ${ }^{[2,3]}$

Gout merupakan penyakit progresif akibat deposisi kristal monosodium urat di sendi, ginjal, dan jaringan ikat lainnya sebagai akibat dari hiperurisemia yang berlangsung kronik. Gout mengenai 1-2\% populasi dewasa, dan merupakan kasus artritis inflamasi terbanyak pada pria. Prevalensi penyakit gout diperkirakan antara 13,6 per 1.000 pria dan 6,4 per 1.000 wanita. Prevalensi gout meningkat sesuai umur dengan rerata $7 \%$ pada pria umur $>75$ tahun dan $3 \%$ pada wanita umur $>85$ tahun. ${ }^{[4]}$

Berdasarkan hasil RISKESDAS (Riset Kesehatan Dasar) tahun 2018, prevalensi penyakit sendi di Indonesia berdasarkan diagnosis dokter pada penduduk umur $\geq 15$ tahun adalah sebesar 7,3\%. Prevalensi berdasarkan provinsi, pada provinsi Sumatera Utara sebesar 5,35\%. Menurut kelompok umur, prevalensi pada umur $<35$ tahun sebesar $5,78 \%$ dan pada usia $\geq 35$ tahun sebesar $94 \%$. $^{[5]}$

Faktor risiko yang menyebabkan orang menderita gout adalah usia, asupan senyawa purin berlebihan, konsumsi alkohol berlebih, obesitas, kurangnya aktivitas fisik, hipertensi dan penyakit jantung, obat-obat tertentu (terutama diuretik), dan gangguan fungsi ginjal. Dari hasil penelitian, diketahui bahwa kadar asam urat orang yang mengonsumsi alkohol dengan frekuensi lebih dari 4 kali seminggu mempuyai kadar asam urat lebih tinggi dibandingkan dengan orang yang mengonsumsi alkohol $\leq 3$ kali seminggu ${ }^{[6]}$ Menurut Astuti dan Tjahjono, minuman yang mengandung alkohol seperti bir, tuak, tape dan lainnya dapat meningkatkan produksi asam urat khususnya pada lakilaki. ${ }^{[7]}$

Data proporsi konsumsi minuman beralkohol meningkat dari 3\% menjadi $3,3 \%$. Prevalensi berdasarkan provinsi, pada provinsi Sumatera Utara sebesar $5,5 \%$ dengan jenis minuman tradisional keruh tertinggi di Indonesia sebesar $71,1 \%$. Menurut kelompok umur, rentang usia 25-29 tahun memiliki prevalensi tertinggi dengan persentase sebesar 5,6\%. Prevalensi menurut jenis kelamin, prevalensi pada laki-laki $6,1 \%$ dan perempuan $0,4 \%$. Menurut tempat tinggal, prevalensi konsumsi minuman beralkohol di perkotaan sebesar $3 \%$ dan di pedesaan sebesar 3,6\%. ${ }^{[5]}$

Tuak adalah jenis minuman beralkohol yang terbuat dari nira pohon aren (Arenga pinnata) atau pohon kelapa (Cocos nucifera). Minuman tuak umumnya memiliki kadar alkohol sekitar $4 \% .{ }^{[8]}$ Tuak sebagai minuman tradisional telah menjadi turun-temurun, di mana konsumsi tuak sangat sulit dihilangkan dari kebiasaan masyarakat.

Berdasarkan data RISKESDAS tahun 2018, prevalensi merokok secara nasional adalah 24,3\%. Prevalensi berdasarkan provinsi, pada provinsi Sumatera Utara $22,4 \%$, berdasarkan jenis kelamin pada laki-laki $47,3 \%$ dan perempuan $1,2 \%$. Menurut kelompok umur, prevalensi tertinggi pada usia 30-34 tahun sebesar $32,2 \%$, sedangkan pada usia 18 tahun sebesar $13,4 \%$. ${ }^{[5]}$

Hasil penelitian diketahui bahwa kadar asam urat perokok lebih rendah dibandingkan dengan yang bukan perokok. ${ }^{[9-11]}$ Pada pria perokok didapati hasil penurunan kadar asam urat sebesar 27\%. Namun, tidak didapati hubungan 
antara merokok dan risiko gout pada wanita. ${ }^{[12]}$ Berdasarkan latar belakang di atas penulis, tertarik melakukan penelitian pengaruh merokok terhadap kadar asam urat pada pria dewasa yang mengonsumsi tuak di Kelurahan Sigulang-gulang Kecamatan Siantar Utara.

\section{METODE}

Penelitian ini merupakan penelitian analitik dengan desain cross sectional dengan jumlah responden sebanyak 56 orang pria usia 26-45 tahun yang terbagi atas 2 kelompok, yaitu 28 orang kelompok merokok dan konsumsi tuak dan kelompok tidak merokok dan konsumsi tuak. Penelitian ini dilakukan pada bulan September hingga bulan November 2019 di Kelurahan Sigulang-gulang Kecamatan Siantar Utara.

Sebelum dilakukan penelitian kepada responden dijelaskan mengenai tujuan penelitian dan setelah responden mengerti dan setuju kemudian responden menandatangani informed consent. Selanjutnya responden diwawancara mengenai derajat merokok (tidak merokok $=0$ batang/hari; ringan $=1-9$ batang/hari; sedang $=10-20$ batang/hari; dan berat $>20$ batang/hari) dan konsumsi tuaknya (ringan $=1-2$ gelas $/$ hari; sedang $=3-4$ gelas/hari; berat $>4$ gelas/hari; 1 gelas $=$ 200ml) dan dilakukan pemeriksaan kadar asam urat dengan menggunakan metode blood uric acid test strip (Autocheck).

Analisis data untuk mengetahui pengaruh merokok terhadap kadar asam urat pada pria dewasa yang mengonsumsi tuak dengan menggunakan uji t-dependen. Sedangkan analisis data untuk mengetahui hubungan derajat merokok dengan kadar asam urat dan derajat konsumsi dengan kadar asam urat dengan menggunakan uji chi-square. Analisis statsitik ini dilakukan dengan menggunakan software SPSS.

\section{HASIL}

\section{Karakteristik Responden}

Penelitian dilakukan pada 56 orang laki-laki. Berdasarkan tabel 1, didapatkan distribusi usia tertinggi adalah usia 26-35 tahun sebesar 58,9\%.Lebih dari separuh responden bekerja sebagai wiraswasta yaitu sebesar 60,7\%.Separuh dari responden merupakan perokok dengan derajat sedang sebagai derajat perokok tertinggi yaitu sebesar $25 \%$ dan derajat konsumsi tuak tertinggi adalah jenis ringan $46,4 \%$.

Tabel 1. Karakteristik Responden

\begin{tabular}{rcc}
\hline \multicolumn{1}{c}{ Variabel } & $\begin{array}{c}\text { Frekuensi } \\
(\mathbf{n = 5 6})\end{array}$ & $\begin{array}{c}\text { Persentase } \\
(\mathbf{\%})\end{array}$ \\
\hline Usia & & \\
26-35 tahun & 33 & 58,9 \\
36-45 tahun & 23 & 41,1 \\
Pekerjaan & & \\
Buruh & 4 & 7,1 \\
Pedagang & 4 & 7,1 \\
PNS & 5 & 8,9 \\
Supir & 9 & 16,1 \\
Wiraswasta & 34 & 60,7 \\
Pendidikan & & \\
Terakhir & & \\
SD & 2 & 3,6 \\
SLTP & 12 & 30,4 \\
SLTA & 26 & 46,4 \\
Sarjana & 11 & 19,6 \\
Derajat & & \\
Merokok & & \\
Tidak Merokok & 28 & 50,0 \\
Ringan & 3 & 5,4 \\
Sedang & 14 & 25,0 \\
Berat & 11 & 19,6 \\
Derajat & & \\
Konsumsi Tuak & & 46,4 \\
Ringan & 26 & 39,3 \\
Sedang & 22 & 14,3 \\
Berat & 8 &
\end{tabular}

Kadar Asam Urat Rata-rata pada Pria Dewasa Peminum Tuak yang Merokok dan Tidak Merokok

Tabel 2 menunjukkan hasil uji tdependen nilai asam urat kelompok merokok dan konsumsi tuak sebesar 6,01 $\pm 1,09$ sedangkan pada kelompok tidak merokok dan konsumsi tuak sebesar 
$7,31 \pm 1,20$. Pada analisa uji t-dependen didapati nilai $\mathrm{p}$ sebesar 0,001. Hal ini berarti ada perbedaan yang bermakna pada kadar asam urat kelompok merokok dan konsumsi tuak dengan kelompok tidak merokok dan konsumsi tuak.

Tabel 2. Perbedaan Kadar Asam Urat Merokok dan Konsumsi Tuak dengan Tidak Merokok dan Konsumsi Tuak

\begin{tabular}{ccc}
\hline \multicolumn{2}{c}{ Nilai Kadar Asam Urat } & Nilai \\
$\begin{array}{c}\text { Konokumsi } \\
\text { Tuak }\end{array}$ & $\begin{array}{c}\text { Tidak Merokok } \\
\text { dan Konsumsi } \\
\text { Tuak }\end{array}$ & $\begin{array}{c}\text { P } \\
6,01 \pm 1,09\end{array}$ \\
\hline
\end{tabular}

Hubungan Derajat Merokok dengan Kadar Asam Urat

Tabel 3 menunjukkan hubungan antara derajat merokok dengan kadar asam urat. Pada hasil uji chi-square, nilai yang dipakai adalah nilai pada Pearson chisquare. Nilai $p$ yang didapat adalah 0,552 (p>0,05). Hal ini berarti tidak ada hubungan antara derajat merokok dengan kadar asam urat.

\section{Hubungan Derajat Konsumsi Tuak dengan Kadar Asam Urat}

Tabel 4 menunjukkan hubungan derajat konsumsi tuak dengan kadar asam urat. Pada hasil uji chi-square, nilai yang dipakai adalah nilai pada Pearson chisquare. Nilai $p$ yang didapat adalah 0,001 $(\mathrm{p}<0,05)$. Hal ini berarti ada hubungan antara derajat konsumsi tuak dengan kadar asam urat.

\section{PEMBAHASAN}

Kadar Asam Urat Rata-rata pada Pria Dewasa Peminum Tuak yang Merokok dan Tidak Merokok

Tabel 2 menunjukkan bahwa dari uji korelasi didapatka nilai $\mathrm{p}$ sebesar 0,001 $(<0,05)$ yang berarti ada hubungan antara kadar asam urat kelompok yang merokok dan konsumsi tuak dengan kelompok tidak merokok dan konsumsi tuak. Hasil penelitian ini menunjukkan kadar asam urat kelompok yang merokok memiliki kadar asam urat lebih rendah dibandingkan kelompok yang tidak merokok.

Tabel 3. Hubungan Derajat Merokok dengan Kadar Asam Urat pada Pria Dewasa Peminum Tuak

\begin{tabular}{|c|c|c|c|c|c|c|c|c|}
\hline & \multicolumn{4}{|c|}{ Kadar Asam Urat } & \multirow{2}{*}{\multicolumn{2}{|c|}{ Total }} & \multirow[t]{3}{*}{$p($ Sig $)$} \\
\hline & & \multicolumn{2}{|c|}{ Normal } & \multicolumn{2}{|c|}{ Hiperurisemia } & & & \\
\hline & & $\mathbf{n}$ & $\%$ & $\mathbf{N}$ & $\%$ & $\mathbf{N}$ & $\%$ & \\
\hline \multirow{3}{*}{$\begin{array}{l}\text { Derajat } \\
\text { Merokok }\end{array}$} & Ringan & 3 & 10,7 & 0 & 0 & 3 & 10,7 & \multirow{3}{*}{0,552} \\
\hline & Sedang & 13 & 46,4 & 1 & 3,6 & 4 & 50 & \\
\hline & Berat & 9 & 32,2 & 2 & 7,1 & 1 & 39,3 & \\
\hline Total & & 25 & 89,3 & 3 & 10,7 & 8 & 100 & \\
\hline
\end{tabular}

Tabel 4. Hubungan Derajat Konsumsi Tuak dengan Kadar Asam Urat

\begin{tabular}{|c|c|c|c|c|c|c|c|c|}
\hline & & \multicolumn{3}{|c|}{ Kadar Asam Urat } & \multicolumn{2}{|c|}{ Total } & \multirow[t]{3}{*}{$p$ (Sig) } \\
\hline & & \multicolumn{2}{|c|}{ Normal } & \multicolumn{2}{|c|}{ Hiperurisemia } & & & \\
\hline & & $\mathbf{n}$ & $\%$ & $\mathbf{n}$ & $\%$ & $\mathbf{n}$ & $\%$ & \\
\hline \multirow{3}{*}{$\begin{array}{l}\text { Derajat } \\
\text { Konsumsi } \\
\text { Tuak }\end{array}$} & Ringan & 23 & 41 & 3 & 5,4 & 26 & 46,4 & \multirow{3}{*}{0,001} \\
\hline & Sedang & 14 & 25 & 8 & 14,3 & 22 & 39,3 & \\
\hline & Berat & 1 & 1,8 & 7 & 12,5 & 8 & 14,3 & \\
\hline Total & & 38 & 67,8 & 18 & 32,2 & 56 & 100 & \\
\hline
\end{tabular}


Merokok merupakan kegiatan membakar rokok, kemudian menghisapnya dan menghembuskannya keluar melalui hidung dan / atau mulut. Asap rokok yang dihirup oleh seorang perokok mengandung komponen gas dan partikel yang berpotensi menimbulkan radikal bebas. ${ }^{[9]}$

Untuk menanggulangi radikal bebas, tubuh mempunyai sistem pertahanan yang disebut antioksidan. Antioksidan ada yang berasal dari luar tubuh yang disebut dengan antioksidan eksogen antara lain vitamin $\mathrm{C}$ dan vitamin E. ${ }^{[15]}$ Antioksidan yang berasal dari dari dalam tubuh disebut antioksidan endogen. Salah satu antioksidan endogen dalam tubuh adalah asam urat. Asam urat dipakai untuk melawan radikal bebas yang ditimbulkan oleh asap rokok sehingga kadar asam urat plasma perokok dapat menurun. ${ }^{[10,13]}$

Hasil penelitian ini sejalan dengan penelitian yang dilakukan oleh Mouhamed yang dilakukan pada 300 responden dan ditemukan perbedaan rata-rata yang signifikan $(\mathrm{p}=0,0003)$ antara kelompok yang merokok dan tidak merokok yaitu

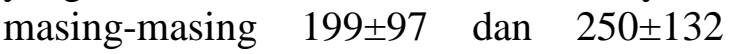
(rata-rata $\pm \mathrm{SD}$ ). ${ }^{[10]}$ Hal yang sama juga terjadi pada penelitian yang dilakukan oleh Fariduddin \& Masih didapati nilai $p$ sebesar 0.001 yang artinya sama yaitu terdapat perbedaan rata-rata yang signifikan antara kelompok merokok dan tidak merokok. ${ }^{[11]}$

\section{Hubungan Derajat Merokok dengan Kadar Asam Urat}

Tidak terdapat hubungan antara derajat merokok dengan kadar asam urat $(p>0,05)$. Hal ini dapat terjadi karena jumlah responden yang kecil yaitu 28 orang dan responden dibagi menjadi 3 kategori yaitu perokok ringan, sedang dan berat.

\section{Hubungan Derajat Konsumsi Tuak dengan Kadar Asam Urat}

Terdapat hubungan antara derajat konsumsi tuak dengan kadar asam urat, dimana hasil uji bivariat dengan menggunakan uji chi-square didapatkan nilai $p=0,001$. Hal yang sama juga terjadi pada penelitian yang dilakukan oleh Montol dan Rotinsulu yang dilakukan pada 49 responden dan didapati nilai $\mathrm{p}$ sebesar $0,048(\mathrm{p}<0,05)$, yang artinya sama yaitu terdapat hubungan antara derajat konsumsi tuak dengan kadar asam urat. ${ }^{[6]}$

Tuak mengandung kadar alkohol $4 \%$. Alkohol dapat meningkatkan kadar asam urat di dalam serum melalui penurunan eksresi asam urat dan peningkatan produksi asam urat. Penurunan ekskresi asam urat dari ginjal terjadi karena alkohol dapat meningkatkan asam laktat pada darah yang menghambat eksresi asam urat. $^{[16]}$ Alkohol juga dapat mempercepat proses pemecahan adenosin trifosfat dan produksi asam urat. ${ }^{[17]}$ Metabolisme etanol menjadi acetyl CoA menjadi adenin nukleotida meningkatkan terbentuknya adenosin monofosfat yang merupakan prekursor pembentuk asam urat.Oleh karena hal tersebut, konsumsi tuak yang berlebihan akan menyebabkan terjadinya metabolism purin yang berlebihan di dalam tubuh, sehingga pembentukan asam urat di dalam darah akan meningkat. Selain itu, dengan terhambatnya proses ekskresi asam urat maka secara otomatis asam urat dalam darah akan terus meningkat dan melebihi nilai normal. ${ }^{[18,19]}$

\section{KESIMPULAN}

Pada penelitian ini ditemukan hasil :

1. Terdapat perbedaan yang bermakna pada kadar asam urat pria yang merokok dan mengonsumsi tuak dengan pria yang tidak merokok dan mengonsumsi tuak.

2. Tidak ditemukan hubungan yang bermakna antara derajat merokok dan kadar asam urat.

3. Terdapat hubungan yang bermakna antara derajat konsumsi tuak dan kadar asam urat dengan nilai $p$ sebesar 0,001 . 


\section{SARAN}

Berdasarkan hasil penelitian dan pembahasan peneliti ingin memberikan saran kepada pihak yang terkait antara lain: kepada peneliti selanjutnya agar dilakukan penelitian lebih lanjut mengenai pengaruh merokok terhadap kadar asam urat dengan jumlah responden yang lebih banyak, kepada petugas kesehatan di wilayah kerja Kelurahan Sigulang-gulang Kecamatan Siantar Utara agar melakukan kegiatan penyuluhan kesehatan mengenai bahaya konsumsi tuak dan penyakit asam urat bagi masyarakat, kepada penderita asam urat untuk berhenti mengonsumsi tuak untuk menurunkan kadar asam urat serum.

\section{DAFTAR PUSTAKA}

[1] Ridi RE, Tallima H. Physiological functions and pathogenic potential of uric acid: a review. J Adv Res. 2017;8(5):487-93. doi: 10.1016/j.jare.2017.03.003

[2] Kemenkes RI. Panduan Praktik Klinis bagi Dokter di Fasilitas Pelayanan Kesehatan Primer. $1^{\text {st }}$ ed. Jakarta: Ikatan Dokter Indonesia; 2017.

[3] Imanuel S. Buku Ajar Ilmu Penyakit Dalam. $6^{\text {th }}$ ed. Jakarta: Interna; 2017.

[4] Perhimpunan Reumatologi Indonesia. Pedoman Diagnosis dan Pengelolaan Gout. Jakarta: Perhimpunan Reumatologi Indonesia; 2018.

[5] Kemenkes RI. Laporan Nasional RISKESDAS 2018. Jakarta: Lembaga Penerbit Badan Peneliti dan Pengembangan Kesehatan; 2018.

[6] Montol AB, Rotinsulu A. Konsumsi Minuman Beralkohol dan Kadar Asam Urat pada Pria Dewasa di Kelurahan Koya Kecamatan Tondani Selatan Kabupaten Minahasa. GIZIDO. 2014;6(1):1-11.
[7] Astuti STW, Tjahjono HD. FaktorFaktor yang Memengaruhi Kadar Asam Urat (Gout) pada Laki-Laki Dewasa di RT 04 RW 03 Simomulyo Baru Surabaya. Jurnal Keperawatan. 2018;3(2).

[8] Suryanto, Nurbaya S. Pemeriksaan Kadar Alkohol dalam Minuman Tuak. Jurnal Farmanesia. 2016;3(1):22-3.

[9] Hanna BE, Hamed JM, Touhala LM. Serum Uric Acid in Smokers. Oman Med J. 2008;23(4):269-74.

[10] Mouhamed DH, Ezzaher A, Neffati F, Douki W, Gaha L, Najjar MF. Effect of Cigarette Smoking on Plasma Uric Acid Concentrations. Environ Health Prev Med. 2011;16(5):307-12. doi: 10.1007/s12199-010-0198-2

[11] Fariduddin JM, Masih SS. A Comparative Study on Lipid Profile and Uric Acid among Smokers and non-smokers. International Journal of Clinical Biochemistry and Research. 2016;3(4):469-71. doi: 10.18231/2394-6377.2016.0027

[12] Teng GG, An P, Yuan J, Koh W. Cigarette Smoking and Risk of Incident Gout in The Singapore Chinese Health Study. Arthritis Care Res. 2016;68(8):1135-42. doi: 10.1002/acr.22821

[13] Meida NS, Sisindra F. Kadar Asam Urat Plasma pada Perokok dan Non Perokok. Mutiara Medika. 2005;5(1):21-6.

[14] Kim S, Choe J. Association beetween Smoking and Serum Uric Acid in Korean Population. Medicine (Baltimore). 2019;98(7): e14507. doi: $\underline{\text { 10.1097/MD.0000000000014507 }}$

[15] Wijaya H, Junaidi L. Antioksidan Mekanisme Kerja dan Fungsinya dalam Tubuh Manusia. Warta IHP/ Journal of Agro-based Industry. 2011;29(2):44-55. 
[16] Doherty M. New Insights Into The Epidemiology of Gout. Rheumatology (Oxford). 2009;48(Suppl 2):ii2-ii8. doi: 10.1093/rheumatology/kep086

[17] Zhang Y, Woods R, Chaisson CE, Neogi T, Niu J, McAlindon TE, et al. Alcohol Consumption as a Trigger of Recurrent Gout Attacks. Am J Med. 2006;119(9):800. doi: 10.1016/j.amjmed.2006.01.020

[18] Neogi N, Clara C, Jingbo N, Christine C, David J H, Yuqing Z. Alcohol quantity and type on risk of recurrent gout attacks: an internetbased case-crossover study. Am J Med. 2014;127(4):311-8. doi: $\underline{\text { 10.1016/j.amjmed.2013.12.019 }}$

[19] Stibůrková B, Markéta P, Jitka S, Viktor K. Metabolic Syndrome, Alcohol Consumption and Genetic Factors Are Associated with Serum Uric Acid Concentration. PLoS One. 2014;9(5): e97646. doi: $\underline{10.1371 / \text { journal.pone.0097646 }}$ 